\title{
Socio-Psychological Basics of The Study of The Styles of Attitude in Coping by Adolescents
}

\author{
Ostonov Jasur Shopirjonovich \\ Lecturer of The Chair of "Psychology" of the Bukhara State University
}

\begin{abstract}
In this article we will talk about the specific socio-psychological features of coping behavior in adolescents combined with the diagnostical phases of the socio-psychological attitudes.
\end{abstract}

Keywords: stress, coping, diagnostic processes, mental processes, nominal scale, dynamics of results.

\section{INTRODUCTION}

The problem of coping behavior has always been one of the most pressing problems facing humanity. After all, the social development of a person in all respects, his activity and selfdevelopment in the quality of a person depend largely on this due processes process.

\section{Relevance of the topic}

If members of the society have sufficient information about their psychological possibilities, achievements and shortcomings of a certain circle, this will allow them to easily cope with the various difficulties that they face in life, to make more productive use of their opportunities, to form a deeper, positive and peculiar picture about themselves making as sson as possible [1].

In everyday life, there the dynamics, complexity and dependence, therefore, a person must constantly overcome difficulties and oppositions of various manifestations, adapt to the situation, find the best way to complexity. Here is the productive use of all the resources that a person needs, which leads to the fact that he himself adapts to the situation and feels more or less protected. Psychological coping behavior consists in the ability of a person to demand a complicated difficult situation. Overcoming acquisition manifests itself dynamic cognition, as well as the power of personality behavior, directing external or internal forces, in which there is a threat assessment.

\section{REFERENCE REVIEW}

In psychology, the concept of coping behavior came into being in the second half of the twentieth century, when translated from English means "cope, to cope"- to take, overcome. The first of this term is L.Murphy 1962 year used in the process of researching how to cope with the problem during the crisis in children. A.Maslow, however, introduced this term in science. In general, coping behavior is characterized by the readiness of the individual to solve life problems [2].

It manifests itself in the use of opportunities, means to overcome problems, which are characterized by the elimination of stressful behavior. 1) Primary evaluation which means that the event is judged to be either irrelevant, positive or negative to one's wellbeing; and 2) secondary appraisal, which means that different relevant coping strategies are considered before choosing a way to deal effectively with stressor.

Relying on the opinion of many foreign specialists, we can say that coping behavior has a variety of 
strategies and styles that people use only when they are faced with life-threatening situations. There are many different and very different classifications of coping behavior, it is analyzed according to several research directions, styles.

Until now, many of the specialists of the field have studied at a certain level the sides of the problems of psychological protection engineering through their own research. In particular, from foreign psychologists Z.Freud, K. Kol, D. Myers, E. Krechmer, G.Ollport, K. Thomas by Russian scientists. M. Andreyeva, V.S. Merlin, V.V. Stolin, A.N. Leontyev, N.S.Leytes, V.M. Rusalov, O.A.Konopkin, A.V.Petrovsky, Ivan Ognev conducted scientific research on this problem. V.G. Kamensky's work "motivation in the system of psychological protection and conflicts" is devoted to the interpretation of certain levels of conflict situations of psychological protection. In particular, the author cites the existence of different moral views on man in the influence of various conflicting situations through certain means of protection "Ego-protection". Within the framework of the formation of social imagination of psychological protection opportunities in adolescents from Uzbek scientists V.M. Karimova and her peers within the framework of the dynamics of mental development in adolescents E.Gh. Ghoziyev and his students conducted research [5].

\section{Main body}

The concept of "coping strategy" is also broadly analyzed as the management of process resources. According to estimates, the elimination of life complexities is carried out by mobilizing the resources of the individual in essence.

In overcoming the stressful situation, empirical materials with a different determinant and effective magnitude were obtained. Indeed, all the work within the framework of coping behavior relies on a deeply empirical character. Thus, together with colleagues from Falkman and Lazarus, they developed the "ability to take overcome the situations" methodology, which determines the individual's response to an unpleasant 67 phenomenon. Factors analysis motivate to divide into 8 discrete strategies:

$>$ The strategy of overcoming the insistence-unpleasant and hateful problem in relations, the person tries to overcome the situation by means of aggressive force.

$>$ Social distance keeping strategy - an individ separates their problems from the blunder they are trying to unify about.

$>$ Self - control strategy- covers personal senses and attempts to control their own affairs.

$>$ Strategy - the individ has the power to seek information, material and emotional support from society.

$>$ The strategy for obtaining insight-the result of the problem caused by his role, the previous answer involves trying not to repeat his mistakes again.

$>$ Strategy of escape - man has the power to gather and escape from the problematic situation to become being get rid of as a hero.

$>$ A planned solution strategy is to build a plan and increase it by trying to reach its fulfillment.

$>$ A positive evaluation strategy is the use of positive terms in overcoming difficulty, interpreting action, and its positive reception by a person [6].

The strategies used in the above complex situations of 8 life are completely different from each other according to the individual's goal acquisition. In order to correct such situations, the person either attacks those around him, either tries to get help from them, either tries to avoid this situation, either distinguishes the problem to himself, either tries to assess the situation positively, or tries to focus all 
his attention on the emotional state and the personality (keeps his feelings in order not to make mistakes in the Although in fact these strategies are a few exceptions, sometimes they complement each other. The results of the practice showed that every second person who faced a problem situation was using several soping strategies at the same time. A number of researchers estimated that the effective use of several methods in eliminating the negative phenomenon would give the opportunity to master practical steps. Strategies in avoidance and re-positive evaluation strategies noeffektiv strategies out-of-date re-positive evaluation strategies are a trap in crisis time, giving positive importance to a complex situation in such a situation paves the way for the occurrence of emotional stress while reducing distress. Along with this, this legislative attitude distracts us from the problem that we need to solve in practice. While strategies of escape are clearly evident in the process of degradation forthcoming.

Many authors confirm that coping has many complexities in limiting behavior and protections (Libina, Lipin, 1998).

According to R. Lazarus coping behavior as a passive psychological protection, the parameters between coping of protection and coping mechanisms were differentiated and determined:

1. Temporary orientation. According to the rule of protection, the situation is resolved "now", the acute situation will have nothing to do with the next situation, that is, the acute psychological protection will serve the acute psychological comfort.

2. Instrumental orientation. Here the mechanism defensively "thinks" only about itself, if its interests tenderly-in the direction of the surrounding, too, it will discuss its interests in the first place.

3. Objective-functional significance. Whether bundamm is able to control the function of disturbances in relations with the environment and people (coping behavior) or, only, it performs the function of controlling the emotional state (mechanizms of protection).

4. Modality of management. Whether the role of the action in the search for information is directly realized, whether the reflection (coping is related to behavior) or occurs under pressure, etc. [6]

According to L.I. Antsiferova the main task of the protective forces, different from coping, is to control and suppress the negative psychological state caused by stressors, while the stressor continues its work. He also noted that "... in a problematic and stressful situation, people who are prone to psychological protection perceive the world as a man of danger, self-assessment falls and begin to look at the world with a pessimistic glance. And people who approach this situation through a counter-strategy are considered to be people who have an optimistic attitude, they evaluate themselves positively and firmly, express a manifestation of real approach to life and a strong motivation in themselves [3].

B.D. Karvasarsky in his research, he looks at psychological defenses and coping patterns as an individual's adaptive process. If (according to R. Lazarus) coping process is directed to the active change of the situation and the satisfaction of a significant need, then the process of compensation will be directed, in particular, to the mitigation of the protective psychic diskomfort.

For psychological protection and limitation of perceived coping strategies V.A.Tashlikov presents his turn-by-turn analysis scheme.

1. Inertialism. The mechanism of psychological protection is not adapted to the rigid situation requirement. And the perceived technique of self-control will be low-key and adapted to the situation.

2. Direct and delayed effects. Psychological defenses try to reduce the emotional tension that occurs 
as rapidly as possible. But through the use of control, which a person understands, can also lead to more grief and, even sometimes, to compression.

3. Tactical and strategic effects. Psychological defenses can only arouse tension in the conversational process, according to kaltabinlik, (princip of "here and now"), in which coping strategies are viewed on account of the prospect.

4. Objectiv different dimensions in perception of the situation. Psychological defenses lead to an incorrect perception of the real state. Self-control is associated with Real perception as well as the ability to be in an object relationship.

1-table. Demonstration of the basic strategies of behavioral patterns of puberty in adolescents

\begin{tabular}{|l|l|l|l|l|l|}
\hline \multirow{2}{*}{ № } & \multirow{2}{*}{ Age groups Groups } & \multicolumn{3}{|c|}{ Forms of situational problems } \\
\cline { 3 - 6 } & & \multicolumn{2}{|c|}{ Indirect } & \multicolumn{2}{c|}{ Direct } \\
\cline { 3 - 6 } & & Verbal & Nonverbal & Verbal & Nonverbal \\
\hline 1. & Age 10-11 & 41 percent & 48 percent & 32 percent & 40 percent \\
\hline 2. & Age 12-13 & 58 percent & 47 percent & 49 percent & 41 percent \\
\hline 3. & Age $14-15$ & 69 percent & 48 percent & 51 percent & 36 percent \\
\hline
\end{tabular}

The same thing is revealed that 48 percent of children aged 10-11 years have direct nonverbal behavior and 32 percent have direct verbal behavior in rare cases. In 58 percent of adolescents 12-13 years of age, strategic behaviors of direct verbal character are more than threeraydi. In the secondary place in the frequency of percentages, the Bavarian verbal strategic behavior is observed (49 percent). When it comes to adolescents aged 14-15, direct strategic behavior appears to be in the first place (69 percent), which is 11 percent higher than the activity form of adolescents aged 12-13, and 28 percent higher than those aged 10-11 [7].

\section{RESULTS}

In general, during the adolescence period, there is a pronounced manifestation of the dynamics of personality activity forms from the age of a small teenager to the age of a large teenager.

At the same time, in older adolescents, the verbal forms of activity begin to prevail in the conditions of conflicts.

Analysis of the data obtained recognizes the significant impact of the environment, above all, on the level of family predisposition to conflict in adolescents.

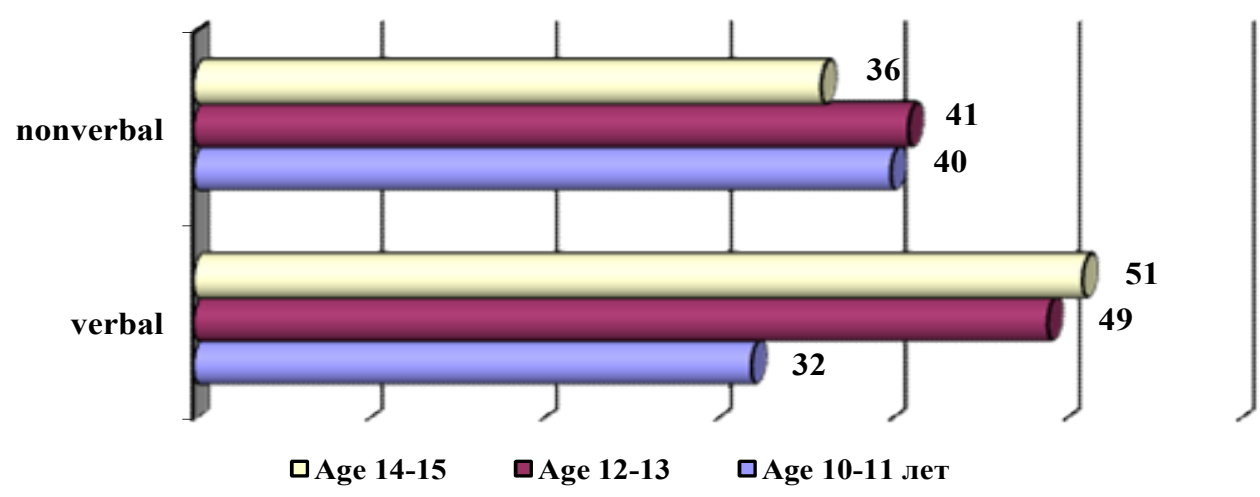

Figure 1. The appearances of attitude of direct overcoming in the youth aged 10-15. 
In our opinion, this situation is explained by the fact that adolescents are particularly susceptible to changes in the microclimate and concrete situation. One of the most important elements of a personforming microclimate is the family. Here said that its composition is not a complete, incomplete, divorced family, but a mutually acceptable relationship between an adult member of the family, an adult and an adult, and children, is of decisive importance. In crisis situations, the frequency of manifestation of various forms of overcoming behavior is sharply different from that of sexual arousal.

\section{CONCLUSION}

Formation of constructive engagements abilities of crisis situations in adolescence is the management of the system of relations of the individual, in essence, the organization of circulation by the Indians in the development of their generality. Here psychologist serves as the subject of managerial (psychocorrection) influences to develop cognitive behavioral patterns in adolescents. Also, the problem of correction of coping behavior in adolescents is now considered topical.

\section{REFERENCES:}

1. Ananyev B.G., Paley I.M. O psixologicheskoy strukture lichnosti / B.G. Ananyev, I.M. Paley // Problemi lichnosti. - M., 2009.

2. Bassin F.V. Problema bessoznatel'nogo $\mathrm{v}$ neosoznavaemikh formakh visshey nervnoy deyatelnosti / F.V. Bassin. - M.: Medisina, 2008. - 468 s.

3. Leont'ev D.A. Samorealizasiya i sushnostnie sili cheloveka / D.A. Leontyev // Psixologiya s chelovecheskim lisom: gumanisticheskaya perspektiva psixologii / Pod red. D.A. Leontyeva, V.G. Shur. - M.: Smisl, 1997. - C. 156-176.

4. Selye H. The stress of life / H. Selye. - N.Y., 1999. - 216 p.

5. A.M. Nazarov. The role of temperament in human behavior. International scientific research journal. Volume 2, Issue 5, May, 2021. - P. 60-68.

6. Barotov Sh.R. Psixologik xizmat. Magistrlar uchun darslik. "Durdona" nashriyoti. - Toshkent 2018. - 384 bet.

7. Sh.Sh. Rustamov. Analiz psikhologicheskikh dannix $\mathrm{s}$ pomoshyu programmi SPSS. Informasionnaya kultura sovremennogo detstva. Sbornik statey Mejdunarodnoy nauchnoprakticheskoy konferensii Rossiya, g. Chelyabinsk, 31 oktyabrya - 1 noyabrya 2019 goda. 